\title{
Training of Classroom Action Research for Science Teachers on Padang Pariaman's SMPN 1, SMPN 2 Sintuk Toboh Gadang and SMPN 1 V Koto Kampung Dalam
}

\author{
Tuti Lestari ${ }^{\# 1}$, Rahmah Evita Putri ${ }^{\# 1}$ \\ 1 Jurusan Pendidikan IPA FMIPA UNP \\ (Universitas Negeri Padang, J1. Prof Dr. Hamka Air Tawar, 25171, Indonesia) \\ *Correspondence: rahmahep@fmipa.unp.ac.id; Tel.: +6285760598611
}

Diterima 28 Februari 2018, Disetujui 8 Maret 2018, Dipublikasikan Maret 2018

\begin{abstract}
To improve the quality of learning and reflect on learning outcomes are things that really improve science teacher profesionalism. That is the biggest motivation for Universitas Negeri Padang's community service team to make a training session about science learning on Padang Pariaman's. Understanding the classroom action reaserch, science teachers can solve the learning problems and write their own scientific work. The purpose of this training are teachers can make their own classroom action research and do their own research untill they can make theirown journals. The result shows that the training was good and reach the target that reaserchers make. $16^{\text {th }}$ proposal finished are more than enough. Proposal are the result from traning, with a lot of revition before the proposal really finished.
\end{abstract}

Keywords - Classroom Action Research, Research training, Teachers

Key words: Classroom Action Research, Research training, Teachers

\section{Pendahuluan}

Berkembangnya ilmu pengetahuan dan teknologi pada era yang serba canggih ini, kesiapan guru untuk meningkatkan profesionalismenya dalam pembelajaran sangat diperlukan. Untuk kesiapan tersebut, pemerintah, dalam hal ini kementrian pendidikan nasional secara berkesinambungan mempersiapkan program pelatihan untuk guru-guru sesuai dengan tuntutan zaman. Salah satunya adalah sertifikasi guru dalam jabatan ${ }^{[6]}$. Program ini bermuara pada profesionalisme guru dengan sertifikat yang diperolehnya.

Program sertifikasi tersebut merupakan salah satu aplikas dari Undang-Undang Republik Indonesia No. 14 pasal 1 ayat 1, tahun 2005, yang menyatakan guru adalah pendidik profesional dengan tugas utama mendidik, mengarahkan, menilai dan mengevaluasi peserta didik pada pendidikan anak usia dini jalur pendidikan formal, pendidikan dasar dan menengah. Pada pasal 10 ayat 1 , dinyatakan bahwa setiap guru seharusnya memiliki 4 kompetensi yaitu kompetensi pedagogis, kompetensi kepribadian, kompetensi sosial dan kompetensi profesional.

Sebagai implementasi dari kompetensi pedagogis guru, salah satu materi yang berkaitan dengan standar isi pada kurikulum 2013 dalam program sertifikasi guru adalah pengetahuan penelitian tindakan kelas (PTK) di sekolah pendidikan dasar dan menengah. Penelitian tindakan kelas berfokus kepada kegiatan pencarian solusi dan dari suatu masalah yang didasari pada suatu langkah ilmiah. Kegiatan ini melibatkan guru secara aktif karena permasalahan yang diangkat adalah permasalahan yang dihadapi oleh guru langsung terkait dengan peran-perannya saat melakukan proses belajar mengajar.

Dari beberapa jenis PTK yang disarankan, jenis PTK partisipanlah yang biasanya dilakukan oleh guru saat ini ${ }^{[11]}$. Sesuai dengan namanya, PTK partisipan dilaksanakan dengan keterlibatan langsung guru yang akan melaksanakan penelitian dalam proses penelitian sejak awal sampai dengan diperolehnya hasil penelitian berupa penyusunan laporan. 
Dalam beberapa tahun ini, guru di beberapa daerah di Sumatera Barat tidak merasa asing lagi dengan istilah PTK. Dari hasil wawancara informal dengan mitra, PTK sudah sering disosialisasikan di sekolah mereka, baik dalam wadah MGMP maupun dari dinas pendidikan dan Universitas Negeri Padang. Namun, pengetahuan tersebut kurang ditindaklanjuti dengan pelaksanaan PTK itu sendiri sehingga kebiasaan untuk merefleksikan hasil pembelajaran kurang terlihat. Ketika mengajar tidak jarang para guru menemukan kesulitan dalam proses belajar mengajar di kelas. Guru-guru mengalami kesulitan dalam menerapkan metode pengajaran yang cocok dengan keadaan mayoritas peserta didik. Selain itu, nila ada permasalahan yang terkait dengan proses pembelajaran, guru-guru kesulitan menemukan solusi yang tepa untuk permasalahan tersebut.

Kesulitan-kesulitan ini juga sering dihadapi oleh guru-guru di beberapa daerah tertentu di Sumatera Barat. Permasalahan yang paling sering dialami, salah satunya terkait dengan usaha mengembangkan kemampuan mengajar dikelas terutama dalam mata pelajaran IPA, usaha untuk mencari strategi yang sesuai dengan konsep materi ajar tentunya terkait dengan kinerja guru yang dituntut untuk selalu tampil profesional.

Selain itu, apabila guru-guru secara efektif mampu melaksanakan penelitian tindakan kelas, tidak hanya membantu dalam kualitas pengajaran, guru-guru pun akan terbantu dalam peningkatan angka kredit sebagai ketentuan naik pangkat atau golongan. Dengan melakukan penelitian tindakan kelas, guru-guru secara tidak langsung juga akan menulis karya ilmiah, yang tentu saja memiliki poin khusus dalam angkat kredit kenaikan golongan. Secara gamblang dapat dinyatakan bahwa, melakukan penelitian tindakan kelas memberikan keuntungan menyeluruh bagi guru.

Keadaan ini tidaklah semudah yang diharapkan karena pada kenyataanya, ditemukan bahwa guru-guru SMP, khususnya di SMP Negeri 1, 2 Sintuk Toboh Gadang, SMP Negeri 1 $\mathrm{V}$ Koto Kampung Dalam, terutama guru-guru IPA, masih belum memahami bagaimana cara melakukan penelitian tindakan kelas. Padahal sudah jelas upaya ini mampu membantu guru dalam memecahkan berbagai permasalahan khususnya yang terkait dengan mutu pembelajaran. Oleh karena itu, tentu perlu adanya usaha dari berbagai pihak untuk memberikan pembinaan khusus kepada guru-guru ini, terkait dengan pelaksanaan penelitian tindakan kelas.

Dari analisis situasi, tim bermaksud untuk berupaya mengatasi permasalahan ini dengan memberikan pelatihan penyusunan penelitian tindakan kelas bagi guru IPA SMP Negeri 1,2 Toboh Gadang dan SMP Negeri 1 V Koto Kampung Dalam Kabupaten Padang Pariaman. Secara eksplisit tujuan kegiatan ini adalah melakukan workshop penyususnan proposal PTK guru-guru IPA ke tigas SMP yang menjadi sasaran kegiatan.

\section{Solusi/Teknologi}

Kegiatan ini memadukan konsep/teori tentang PTK dan pelatihan. Oleh sebab itu, teknik penyampaian materi yang dapat meningkatkan pemahaman konsep, pelatihan penentuan masalah dalam pembelajaran dan dikaitkan dengan teori untuk pemecahan masalah pembelajaran dalam PTK, penyusunan proposal telah dilakukan semaksimal mungkin dan seoptimal mungkin dengan menggunakan participatory approach.

Sebelum penyajian materi, peserta diberikan pertanyaan tertulis untuk mengetahui pengetahuan peserta tentang penelitian tindakan kelas (PTK). Kemudian terdapat tiga kegiatan rinci yakni : (1) Penyajian : untuk pengenalan konsep/makna PTK, dilakukan dengan expository technique, dan question and answer dengan menggunakan media pembelajaran yang sesuai. (2) Pelatihan : untuk meningkatkan keterampilan penyusunan proposal PTK dengn individual expository, pair work, dan atau group work (group discussion). (3) Evaluasi : untuk mengetahui sejauh mana kemampuan peserta menyusun proposal, mereka ditugasi membuat draf proposal PTK yang disesuaikan dengan mata pelajaran yang dibinanya dan digunakannya untuk ke lembaga terkait untuk dibiayai atau biaya sendiri (sekolah).

Langkah-langkah penerapan IPTEKS sebagai berikut : (1) Ceramah dan diskusi, 
metode ini merupakan pengantar pada kegiatan inti. (2) Latihan terbimbing dalam menyusun rancangan proposal PTK. (3) Praktek penyusunan proposal PTK secara mandiri oleh peserta.

Keterkaitan antara peserta sebagai mitra tim pelaksana adalah pada bidang ilmu dan pembelajaran yang sama, dengan terjadinya proses take and give. Untuk mengetahui pencapaian luaran ini, maka dilakukan kegiatan evaluasi. Tujuan dari evaluasi adalah memanfaatkan informasi yang diperoleh sebagai acuan dalam menentukan perlakuan selanjutnya. Evaluasi dilakukan pada 1)awal kegiatan orientasi, dan 2) akhir pelaksanaan pelatihan. Evaluasi pada kegiatan awal dilakukan dengan tes pendahuluan, tujuannya untuk mengetahui sejauh mana kemampuan peserta pelatihan tentang PTK. Evaluasi akhir kegiatan dilakukan untuk mengetahui tingkat keberhasilan yang diterapkan oleh masing-masing peserta.

Indikator keberhasilan kegiatan ini dapat dilihat dari terealisasinya penyusunan draf proposal PTK kedua bidang studi yang menajdi subjek penelitian dalam kegiatan ini. Hasil tes pendahuluan tentang PTK merupakan titik awal untuk melihat seberapa jauh peningkatan pengetahuan dan keterampilan peserta. Umpan balik dalam penyusunan proposal PTK tersebut juga merupakan evaluasi proses kegiatan ini. Tingkat keakuratan dan keterkaitan antar bagian rancangan proposal dievaluasi. Namun, keberadaan proposal yang dirancang merupakan indikator utama dalam menentukan keberhasilan kegiatan. Umpan balik dalam proses pelatihan juga merupakan indikator yang dilihat.

\section{Hasil dan Diskusi}

Hasil tes pendahuluan dengan pertanyaan yang meminta peserta menjelaskan kapan suatu siklus dapat berakhir, pelaksanaan tindakan dan observasi secara simultan, dan alasan dimasukkan interpretasi dalam kegiatan observasi, prinsip yang harus diikuti dalam observasi, analisis data sebagai alat bantu merefleksi tindakan dan langkah yang dilakukan guru setelah diperoleh hasil analisis dan refleksi.

Dari 24 orang peserta yang hadir pada hari pertama, hanya 18 orang yang menyerahkan jawaban tes yang diberikan. Dari hasil jawaban peserta tergambar bahwa sebagian besar peserta belum memahami konsep penelitian tindakan kelas. Terlihat hanya 2 orang yang dapat menjawab dengan tingkat keakuratan 60-80\%. Sementara itu, 5 orang menjawab pada tingkat keakuratan $31-50 \%$. Ada 11 orang yang menjawab jauh dari yang diharapkan. Secara menyeluruh berada pada tingkat keakuratan 10$30 \%$.

Berdasarkan jawaban yang diberikan, kelihatannya peserta belum memahami bahwa prinsip PTK yang mendasar, bahkan ada yang hanya menyalin pertanyaan yang diajukan. Peserta cendrung memberikan jawaban semua pertanyaan yang mengarah hanya kepada penilaian pembelajaran, bukan kepada ruang lingkup PTK secara menyeluruh. Dengan kata lain pemahaman peserta mengenai ikhwal PTK memang sangat terbatas. Oleh sebab itu, penyajian materi berupa konsep dan teori PTK perlu disampaikan secara mendasar.

Pada dasarnya peserta kurang memahami antara PTK dan penelitian pada umumnya. Ini terlihat dari banyaknya keheningan yang terjadi dibandingkan dengan respon dari peserta. Kurangnya perhatian guru sebelumnya terhadap kegiatan penelitian karena terfokus hanya pada kegiatan pembelajaran menjadi pemicu keheningan tersebut. Namun, jawaban dari seorang peserta yang menyatakan bahwa PTK merupakan penelitian yang dilakukan oleh guru sebagai peneliti dikelasnya untuk keperluan perbaikan pembelajaran, membuat suasana menjadi berubah hangat. Dari penjelasan diketahui bahwa banyak hal yang harus diluruskan terutama perbedaan PTK dan penelitian kelas. Dengan demikian, ulasa teori tentang prinsip utama PTK serta karateristik, serta cara kerja PTK perlu disajikan lagi secara praktis.

Kegiatan dilanjutkan dengan tanya jawab dan diskusi. Kesempatan untuk bertanya jawab ini disambut oleh peserta dengan serius dan antusias yang tergambar dari banyak pertanyaan yang diajukan serta tanggapan yang diberikan terhadap pertanyaan dari kolega sendiri. Dari pertanyaan dan pendapat mereka berikan narasumber merasa perlu menjelaskan hal yang terkait secara tidak 
langsung dengan materi pelatihan seperti perbedaan antara pendekatan, metoda, dan teknik, serta strategi yang dilakukan dalam pembelajaran di kelas. Kemudian penjelasan ini berkembang pada beberapa terminologi/ istilah yang ada dalam kurikulum 2013 yang masih kabur bagi sebagian peserta.

Penyusunan proposal PTK tentunya selalu mengaitkan cakupan pengetahuan dan teknik pembelajaran IPA. Oleh sebab itu, para instruktur juga menjelaskan ikhwal masing-masing mata pelajaran berdasarkan kurikulum 2013. Konsep pendekatan saintifik dalam pembelajaran IPA masih menjadi permasalahan tersendiri bagi peserta pelatihan.

Selanjutnya pada peserta mengikuti workshop untuk menulis judul, masalah penelitian dan kemungkinan draf kajian teori. Pada peserta bekerja dalam delapan kelompok yang terdiri atas 3 atau 4 orang guru yang sekolahnya berdekatan ataupun yang dianggap akan bisa berkolaborasi dalam melakukan PTK nantinya. Pada sesi siang ini, sekitar 5 judul penelitian diperoleh dari kelompok kerja tersebut. Setiap judul dibahas satu persatu sehingga mereka bisa memahami kenapa judul yang mereka usulkan belum bisa diterima. Dari 5 judul yang didiskusikan, hanya 2 judul yang memerlukan sedikit perbaikan. Kesalahan yang terjadi pada pengajuan judul ini rata-rata terletak pada fokus masalah dan teori yang digunakan untuk mendukung penyelesaian permasalahan penelitiannya. Pelatihan hari pertama yang seharusnya selesai pada jam 15.00 sore, diundur sampai jam 17.00 sore pada hari jumat tanggal 8 September 2017.

Pada hari kedua, sebelum dilanjutkan pada materi berikutnya, materi yang berhubungan dengan judul yang telah dipilih serta kajian teori yang berkaitan dengan judul, disegarkan kembali untuk dapat dikaitkan dengan materi tentang metode penelitian yang diperlukan. Untuk menentukan metode PTK, diantaranya desain, fokus, instrumen, prosedur, teknik pengumpulan data dan teknik analisis data dan interpretasi data, disajikan dengan memberikan ilustrasi contoh dari beberapa judul yang telah disusun peserta pada hari pertama.

Kegiatan analisis data dan insterpretasi dimaksudkan untuk membekali peserat pelatihan dengan kemampuan menganalisis data yang telah mereka kumpulkan dalam penelitian. Dari data yang telah terkumpul, mereka diharapkan mampu melakukan interpretasi sehingga hasil penelitian jadi bermakna bagi peneliti sendiri dan orang lain yang akan membaca hasil penelitian.

Selanjutnya, kegiatan penjelasan tentang penulisan proposal diulang secara menyeluruh sambil mengecek kembali draf proposal yang telah ditulis pada hari pertama. Pada tahap ini, peserta pelatihan dibimbing secara intensif sehingga mereka dapat meneruskan atau merevisi judul yang telah dirancang pada hari sebelumnya.

Penulisan bagian ke tiga proposal, yakni metode penelitian, dilaksanakan dalam kelompok bidang mata pelajaran masing-masing setelah istirahat makan siang. Pada tahap ini, peserta pelatihan dibimbing secara intensif sampai masing-masing peserta pelatihan menyelesaikan keseluruhan bagian draf proposal PTK, baik mata pelajaran IPA ataupun pelajaran lainnya. Selama mereka membuat proposal, kedua instruktur tetap mendampingi dan selalu bersedia memberikan penjelasan kalau peserta mengalami kesulitan.

Diberi waktu satu minggi bagi peserta untuk memperbaiki dan melengkapi draf yang telah ditulis dalam kerja kelompok di kelas. Pada hari terakhir, 29 September 2017, proposal masingmasing ditampilkan pada diskusi paripurna. Kegiatan hari kedua berakhir pukul 15.00.

Akhir kegiatan pelatihan ini adalah hari Jumat, tanggal 29 September 2017. Kegiatan dilaksanakan setengah hari, yakni sampai pukul 11.00. Kesempatan ini digunakan untuk menampilkan 4 proposal sebagai sampel dari proposal yang telah ada.

Sebagai penutup, kegiatan akhirnya dihadiri oleh kepala sekolah SMP 2 Sintoga dan SMP Negeri 1 V Koto Kampung Dalam pada pukul 11.00 yang ditutup oleh salah seorang instruktur. Dalam sambutannya, Kepala Sekolah SMPN 1 V Koto Kampung Dalam, mewakili 2 kepala sekolah lannya, mengakatakan bahwa sekolahnya sangat membutuhkan kelanjutan dari kegiatan tersebut di tahun mendatang.

Dari 23 peserta pelatihan, ada 16 proposal yang diserahkan sebagai luaran yang diminta. Proposal tersebut merupakan revisi dari proses pengerjaan selama pertemua tatap muka. 
Sebagian besar berasal dari mitra kerja SMPN 1 Sintoga, yakni 11 buah. Yang di harapkan pada kegiatan pengabdian kepada masyarakat ini adalah berupa proposal PTK dari masing-masing atau pasangan peserta pelatihan. Dalam pelatihan ini, draf kasar proposal yang telah mulai ditulis semenjak hari pertama dapat direalisasikan pada akhir kegiatan, yakni tanggal 10 Oktober 2017.

Dari hasil kegiatan pengabdian kepada masyarakat di tiga SMP kabupaten Padang Pariaman ini, pada prinsipnya tercermin berjalan dengan lancar. Pelatihan formal yang dilaksanakan selama tiga hari berakhir dengan cukup memuaskan.

Yang menjadi kendala utama ialah kajian teori yang belum banyak mere baca apalagi menguasai. Hal ini tentu menghambat penulisan teori pendukung. Tidak bisa disangkal bahwa guruguru tersebut sangat kurang membaca. Hal ini juga barangkali menjadi batu sandungan bagi mereka untuk mengadakan penelitian dalam bentuk apapun. Namun, sebagai seorang guru uang profesional, dalam hal ini dengan kemampuan pedagogik, semua usaha untuk memperbaiki pembelajaran seharusnya menjadi suatu keharusan untuk diusahakan ${ }^{[6]}$.

Kemampuan sebagian peserta untuk mengaitkan permasalahan dengan teori tentang solusi yang diperlukan, tidak dapat dipungkiri, juga sangat kurang. Hal ini masih jauh dari harapan yang dituntut oleh kurikulum tentang standar seorang guru sekolah menengah. Metode penelitian dengan segala langkah-langkah yang harus dilakukan dilatih secara sistematis adalah sebagai suatu kesatuan yang tidak terpisahkan dalam desain proposal PTK. Kolaborasi antar guru dan siklus pembelajaran merupakan hal yang diprioritaskan sebagai cir khas PTK. Kesulitan peserta dalam menyusun kegiatan pada tahap-tahao siklus dipersyaratkan, yakni planning, action, obervation, dan reflection masih memerlukan latihan yang berkesinambungan.

Kemampuan guru sendiri belum memadai untuk menentukan topik penelitiannya dan menuliskan rancangan penelitian tersebut. Teori yang belum banyak mereka baca apalagi menguasai juga menghambat penulisan teori pendukung. Tidak bisa disangkal bahwa guruguru tersebut sangat kurang membaca. Hal ini juga barangkali bisa menjadi batu sandungan bagi mereka untuk mengadakan penelitian dalam bentuk apapun. Secara keseluruhan, dari tugas hasil pelatihan yang dikumpulkan terlihat belum semua guru mampu menuliskan kerangka proposalnya dengan seksama.

\section{Kesimpulan}

Berdasarkan pelaksanaan pelatihan penyusunan proposal PTK dan hasil yang dicapai oleh guru IPA SMPN 1, 2 Sintoga dan SMPN 1 $\mathrm{V}$ Koto Kampung Dalam kabupaten Padang Pariaman, dapat disimpulkan beberapa hal. Simpulan tersebut diambil dari proses pertama, yakni tes pendahuluan, proses kegiatan, dan draf proposal.

Banyak dari peserta SMPN kabupaten Padang Pariaman memiliki peluang untuk mengembangkan pengetahuan tentang kiat penentuan permasalahan utama pembelajaran IPA di SMP tempat mereka mengajar. Antusiasme keikutsertaannya cukup tinggi dan motivasi peserta didik cukup baik.

Pada umumnya peserta dari mitra SMPN 1 Sintoga lebih memiliki peluang yang besar untuk melanjutkan penelitian dari proposal yang dihasilkannya. Walaupun demikian, peserta dari 2 mitra yang lain, telah memahami konsep dasar metode ilmiah dalam merancang proposal penelitian tindakan kelas.

Terakhir adalah bahwa sebagian peserta, di dalam kelompok penyusun proposal PTK, telah menyelesaikan konsep dasar proposal secara kasar. Dari rangsangan untuk menjadikan draf proposal tersebut menjadi lebih sempurna sangat diperlukan.

\section{Ucapan Terima Kasih}

Ucapan terima kasih disampaikan kepada mitra yakni guru-guru IPA yang telah ikut serta dalam pelatihan penyusunan PTK SMPN 1, SMPN 2 Sintuk Toboh Gadang dan SMPN 1 V Koto Kampung Dalam Padang Pariaman, dan kepada kepala sekolah yang telah mendukung terlaksananya pelatihan ini.

Ucapan terimakasih juga disampaikan kepada Dr. Kurnia Ningsih, M.A dan Dr. 
Zulyusri, M.P atas partisipasinya dalam memberikan pelatihan kepada guru-guru SMPN 1, SMPN 2 Sintuk Toboh Gadang dan SMPN 1 V Koto Kampung Dalam Padang Pariaman. Terimakasi yang sebanyak-banyaknya diucapkan kepada jurusan Pendidikan IPA UNP untuk dukungan yang diberikan selama kegiatan pengabdian yang berlangsung.

\section{Pustaka}

[1] Arikunto, Suharsimi, Suhardjono, dan Supardi, 2006. Penelitian Tindakan Kelas. Jakarta: Bumi Aksara.

[2] Asrori, Mohammad. 2008. Penelitian Tindakan Kelas. Bandung: CV Wacana Prima.

[3] Badan Standar Nasional Pendidikan. 2006. Standar Isi untuk Satuan Pendidikan Dasar dan Menengah; Standar Kompetensi dan Kompetensi Dasar SMP/Mts. Jakarta: Badan Standar Nasional Pendidikan.

[4] Depdiknas. 2005. Undang-undang No.14 tahun 2005 tentang Guru dan Dosen. Jakarta : Depdiknas.
[5] Depdiknas. 2005. Peraturan Pemerintah Nomor 19 tahun 2005 tentang Standar Nasional Pendidikan. Jakarta: Depdiknas.

[6] Depdiknas. 2007. Permendiknas Nomor 16 tahun 2007 tentang Standar Kompetensi Guru, Jakarta: Depdiknas.

[7] Departemen Pendidikan Nasional. 2007. Buku Saku Kurikulum Tingkat Satuan Pendidikan, Jakarta : Dikti.

[8] Johnson, LouAnne. 2008. Pengajaran yang Kreatif dan Menarik. Jakarta: PT Macanan Jaya Cemerlang.

[9] Jordan, Michael dan Herrel, Adrienne. 2008. Stretegies for Teaching English Language Learners. New Jersey : Pearson Merril Prentice Hall

[10] Kartono, Kartini. 2005. Kamus Lengkap Psikologi. Jakarta : PT. Raja Grafindo Persada

[11] Suanrdi, dan Sujadi, Imam. 2016. Sumber Belajar Penunjang PLPG 2016: Materi pedagogik. Kementrian Pendidikan dan Kebudayaan Direktorat Jendral Guru dan Tenaga Kependidikan. 